\title{
Teachers' Perception of The Professional Competencies and Digital Media Use at Early Childhood Institution in Indonesia
}

\author{
Dyah Retno Fitri Utami, Lita Latiana \\ Semarang State University, Semarang, Indonesia \\ e-mail: dyahretnouf@gmail.com
}

\begin{abstract}
This study focuses on teachers perceptions of the professional competence in the digital age. As a competent teacher is always required to improve knowledge, attitudes and skills continuously and keep up with the times as an effort to improve professional competence. This study aims to: 1) explore the perception of preschool teachers about professional competence, and 2) identify the use of digital media in early childhood learning. The survey was conducted using a questionnaire and reflective essay analysis involving 59 preschool teachers in Indonesia. The data obtained during the study showed that the use of digital media in the learning process in early childhood is needs, but must be adapted with the needs of children and the conditions of resources owned by the institutions. The use of digital media is considered necessary and used for learning purposes only, such as the delivery of learning materials that can not be presented directly to children such as natural disasters, wild animals, and traditional dances. The condition of resources institutions is generally still lacking, such as the ability of educators who have not been optimal because of the availability of skill development sites that have not been supported and inadequate facilities. The recommendations from this study are aimed at teachers to improve their ability to use digital media for learning and for governments to provide access to develop teachers skills in using digital media in learning.
\end{abstract}

Keywords: competence, digital media, early childhood, learning, professional

\section{INTRODUCTION}

The development of knowledge and technology as well as the dynamics of changes that occur in the community make the demand for professionalism in the implementation of teacher tasks is growing because teachers have a strategic role in the field of education. In schools, teachers are one of the determinants of the success or failure of efforts to improve the quality and innovation of education (Fullan, 1992). For teachers of Early Childhood Education (ECE), the competence of professionalism can be measured from the ability of an educator in actualizing the four competencies described into the competence of teachers and leads to professionalism actualization. As stated in the Law of the Republic of Indonesia Number 16 Year 2006 on Teachers and Lecturers Chapter IV Article 10 which explains that "Teacher competence as referred to in article 8 covers pedagogic competence, personality competence, social competence and professional competence obtained through professional education". Therefore, it has generally been believed that the profession needs continuous skills upgrading, as a result of this, teachers are expected to develop high competencies in various teaching skills (Mizikaci, 2006).

Professionalism is a lifelong process that involves enhancing knowledge and skills while managing ethical responsibilities to children, families, colleagues, employers, and society (Castle, 2009). The research mostly confirms that teacher qualifications and competencies significantly affect the quality of teaching provided to young children (Lazar, Darlington, Murray, Royce \& Snipper, 1982; Oden, Schweinhart \& Weikart, 2000), and that higher qualifications in preschool children's teachers contribute to more positive outcomes for those 
children both short term and long term (Kontos \& Wilcox-Herzog, 2001).

Teacher professionalism is required to continue to develop in accordance with the changes and developments of science, technology, and community needs, including the need for quality human resources and have the capability to be able to compete, both at the regional, national, and international levels. In a digital age, teachers need to be flexible and be able to adapt to whatever is thrown their way. New technologies are developed every day that can change the way students learn, and the way teachers teach. Likewise, administrators are changing and updating expectations and learning standards. Being able to adapt is a skill that every modern teacher must have. If it's being able to adapt to the way students learn, the behavior their classroom exhibits, or their lesson plans, it is a definitely a trait that is a must-have particularly in early education, only recently have they suggested professional development that meets the needs of the whole teacher (Chen \& Chang, 2006; Chen \& McCray, 2012).

The ability to use digital media is now viewed as part of the competence of teachers in the digital age. According to Ferrari (Ferrari, 2012) the definition of digital competence is the set of knowledge, skills, attitudes (thus including abilities, strategies, values, and awareness) that are required when using ICT and digital media to perform tasks; solve problems; communicate; manage information; collaborate; create and share content; and build knowledge effectively, efficiently, appropriately, critically, creatively, autonomously, flexibly, ethically, reflectively for work, leisure, participation, learning, socialising, consuming, and empowerment (Ferrari, 2012).

The use of technology and digital media can help the learning process become more efficient without reducing the role of teachers in providing guidance to children and facilitating the learning process in developing aspects of child development as well as integrating learning, growth, and development using digital media.

Basically, education is a process of communication and information from educators to learners containing educational information and has elements of educators as a source of information, the media as a means of ideas review, ideas, and educational materials and learners. Education represents activities and means of a group of people or a community to pass interests, goals, and habits from one generation to the next (Dewey, 2012). In the education process there are learning and teaching activities. Teaching is the activity of conveying knowledge. In these terms, education can be defined also as the process of receiving (learning) and giving (teaching) systematic instruction at a school. The process of imparting and acquiring knowledge heavily depends on one's cognitive abilities. Since the beginning, education has been influenced by a variety of factors such as social, economic, political and media technology. However, the most influential factor is media technology (Loretta, Green, and Hansen, 2012).

Technological developments that occur make a paradigm shift in education, where conventional education that depends on the teacher is deemed no longer able to meet the need for knowledge because this learning model has not been able to serve students in accordance with their respective needs. In addition, the teacher is no longer the sole source of knowledge but the facilitator.

One of the utilization of technological development is the existence of digital media used in early childhood education learning in institutions. In contrast to contemporary childhood experiences, children today not only use traditional toys and materials such as beams, dolls, balls, puzzles, and sand but also utilize digital media in the learning process.

considering the changing of times and various aspects of childhood life, it is necessary to reconceptualize children's games in today's society. Children often use digital interactive technology as one of the dominant activities in the play experience, this technology includes objects such as mp3 players, iPods, game apps and television called "digital media" (IR Berson \& MJ Berson, 2010; NAEYC, 2012; VJ Rideout et al, 2013).

Digital media can present contextual, audio and visual learning materials attractively and interactively in accordance with learning materials, in addition, digital media can save time by facilitating access to the intended information (Ahmet, K. \& Nazenin, F., 2018; Arslan , 2015). The use of well-designed digital media can make learning more effective (Fisch, Shulman, Akerman, \& Levin, 2002; McGee \& Richgels, 2006; Segers \& Verhoeven, 2002; D.A. Lieberman et al., 2015).

Using digital media in learning procces is also supported by the development of computer technology so that not a few early childhood education institutions that enter the computer as one of the learning in the institution or as extracurricular. With the development of digital technology in this era, whether the preschool learning process has taken advantage of developments and how teachers' 
perceptions of professional competence in the digital age will be discussed in this article.

\section{METHOD}

This research is a descriptive research using survey method, where this research does not give any treatment to the respondent. According to Isaac \& Michael in (Priscilla, 2005) survey research is used to answer questions that have been raised, to solve problems that have been posed or observed, to assess needs and set goals, to determine whether or not specific objectives have been met, to establish baselines against which future comparisons can be made, to analyze trends across time, and generally, to describe what exists, in what amount, and in what context. And this study aims to explore teachers' perceptions of professional competence and identify the use of digital media in early childhood education learning institutions.

The survey was conducted using a questionnaire and reflective essay analysis involving 59 pre-school teachers in Indonesia. Data collection is done by using google form service. Through the service, questionnaires were distributed to preschool teachers in Indonesia. This study used questionnaires to spread the sample and be more effective because it can cover a large area.

\section{RESULT AND DISCUSSION}

The use of digital media in early childhood learning process has been widely used by educators. This is the impact of technological developments that occur in the digital era. To reveal the main question of this study in more depth, there are 4 parts that become the main aspects and will be described per section, those are:

\subsection{Use of Digital Media in The Learning Process}

Data obtained from the questionnaire of respondents who are pre-school teachers in the use of digital media such as computers, computer software, learning videos, interactive powerpoint and internet in early childhood learning education are very helpful and agree to be introduced to children. Most of the respondents thought that digital media can build interest, enthusiasm, and curiosity of children in learning something related to the theme of learning in an interesting way. In addition, using digital media such as video learning can be very useful when presenting material that can not be reached or presented directly by the teacher in the learning, so that the teaching and learning process can take place effectively and efficiently by delivering real material though through digital media.

Besides that, respondents revealed that the use of digital media in learning needs to be given but only to provide a memorable and enjoyable learning experience so that use is limited in accordance with the needs and abilities of children for growth and development of children can run in accordance with its stages. According to other opinions of respondents, the use of digital media in less effective learning for children, because children are considered more passive and can reduce the social interaction of children, and on the other hand the teacher's creativity in learning is less if only rely on digital media only.

Various opinions on the use of digital media in early childhood learning there are pros and cons. Through these opinions can be concluded that the learning media has advantages and weaknesses. The advantages of using digital media in learning include:

a) The use of digital media in accordance with the development of the times, can reach the learning materials in a complex and practical.

b) Learning can be presented attractively so as to foster interest and build the spirit of the child.

c) Submission of learning material information can be presented in a real way without seeing directly the learned object such as about weather, climate, natural disaster, marine animals, wild animals, dances, and custom clothes that can be displayed through video.

d) Make learning more effective and efficient if used wisely and tailored to the needs and characteristics of children.

e) There is a lot of content that can be accessed for learning and can be tailored to the learning needs.

Lack of digital media in learning include:

a) The procurement of facilities that require a lot of funds, so not all institutions are able to provide qualified technicians to support the learning process.

b) Not all educators are able to operate and utilize digital media optimally.

c) The excessive intensity of use can lead to dependence on teachers so that teachers' creativity in learning innovation is less than the maximum 
d) The interactions of children with the environment or children with teachers tend to decrease when used in excess.

\subsection{The Availability and Adequacy of Digital Media as Teaching Tools in Early Childhood Institution}

Completeness of instructional media is very important, because it can help give ease in process of delivering material by teacher and acceptance of learning material by the child. Due to the different resource conditions in every early childhood educational institution, not all institutions have the same media facilities. The availability of technological facilities in the form of computers or other digital media in institutions where respondents work shows that only a small number of institutions have sufficient facilities. Most agencies do not yet have support facilities. This is due to the minimal cost and lack of land for the procurement of digital media-based facilities. In addition, other facilities such as the Internet have not many institutions. If there is, an internet facility is only intended for administration purposes and used by teachers for the purposes of developing learning materials. And most institutions where respondents work does not have the facility.

On the one side, the institute has not been able to fulfill the digital media as a teaching tool, on the other side the teachers feel agree and support the use of digital media in learning. This has an impact on the use of a modest digital media, and not infrequently teachers use private facilities to support the learning process, such as the use of laptops and private internet access.

Despite having digital media technology, but most early childhood educational institutions have not been able to meet the needs of digital media as a support tool for learning. Early childhood educational institutions generally apply technologybased learning by utilizing tape recorders, Liquid Crystal Display (LCD) and televisions used for gymnastics activities and watching videos or short films in classical learning. For institutions that have been able to hold computer rooms or multimedia spaces for learning and extracurricular activities, they provide computers that can be used for children individually. Computer learning generally utilizes PowerPoint, Paint and educative games such as puzzles that support the learning process. In addition, the use of multimedia space is used for movie class activities during the peak of the theme takes place.

\subsection{Institutional Administration Support in the Use of Digital Resources in Early Childhood Learning}

The use of digital resources to support the administration in early childhood educational institutions requires specialized staff in assisting the administration process in schools. Most teachers feel that there is a need for specialized staff who handle school administration other than teachers. However, their institutions have not been able to provide adequate facilities and feel the need for teacher empowerment. Proper use of technology can facilitate the work faced.

If able to change circumstances that can take advantage of the use of technology in learning, teachers argue to take advantage of various technologies for the benefit of learning for children by adjusting their age and needs. This is done by changing the environment to be better, providing adequate facilities and support all learning process, without overriding the existing local culture so that children develop in accordance with the demands of the times but still have the uniqueness of the environment where children grow and develop.

\subsection{Competence, Skills, and Knowledge of Educators in Integrating Digital Media in Early Childhood Learning}

As an educator, teachers should always try to improve knowledge, attitudes, and skills on an ongoing basis as an effort to improve professional skills. Teacher's job in the field of profession requires special skills as a teacher that not everyone can do. To be a teacher requires a condition that really must master the ins and outs in the field of education and various other sciences.

The role of teachers in the world of early childhood education is more as a mentor or facilitator, and not just as a transferors of knowledge because science cannot be transferred from teacher to child without activeness from the child itself (Sujiono, 2009). In the learning process, an emphasis is placed on the teacher's thinking in understanding how children think, developing and appreciating children's experiences, presenting materials according to child development and using varied methods in learning to enable children to be active in building their own knowledge. 
The task of educators is essentially closely related to the competence of educators. To be able to perform duties as an educator well, educators should have mastered competence as an educator. Through the development of professional competence of educators, teachers continue to develop their skills in accordance with the times. One of them by utilizing digital media as a medium in learning. By using digital media, teachers feel very happy and helped because. Because the media can be more interesting to learn the child, but also feel worried about using it because it can cause dependency effects if used excessively.

As a competent person, a teacher must be able to perform his duties as an educator in relation to his obligation to provide services to the community and to develop and demonstrate educational behavior in the form of real behavior. Competence refers to the performance of a person in carrying out his work, to become an educator, especially early childhood educators, should have competencies that meet the criteria. The National Association for the Education of Young Children (NAEYC) outlines the initial standards that educators should have, such as:

a) Have an understanding of the development and children characteristics so as to create a conducive learning environment for children.

b) Be able to build good relationships with family and society by understanding that the success of education is inseparable from the participation of family and society.

c) Use appropriate judgment in assessing the learning and learning process.

d) Use an effective development approach appropriate to the age and characteristics of the child and be able to understand and understand the appropriate learning development approach.

e) Able to design, implement and evaluate a meaningful curriculum so as to develop a comprehensive learning for each child.

f) Being a professional early childhood educator.

g) For professional early childhood educators should always strive to improve self-ability on an ongoing basis.

h) Have experience in the world of early childhood education.

Through the initial standards that must be owned, as a consequence teachers should be able to develop their abilities as much as possible continuously, including to become a professional early childhood educator as described previously. As an effort to develop ability and skill in order to continue to develop following the time, respondents do it in various ways such as by growing motivation in order to always learn and try new things related to technology, ask with people who are more expert in their field, looking for info or material independently and participate in training related to digital media and technology.

Various efforts that have been done by the respondent is a form of developing the ability, skills, and knowledge in integrating digital media into learning in early childhood education. But on the way, respondents often experience obstacles. These barriers can come from internal and external factors. Barriers that come from within can be low motivation. While the inadequate obstacles of inadequate facilities because of the price that can not be reached for all institutions of early childhood education that doesn not fully support the needs, such as the lack of availability of training on technology and digital media, and if any, the cost was not small. As a result, most teachers independently develop knowledge about technology and digital media autodidally.

Most of the respondents have attended training and seminars related to technology and digital media, such as web programming, animation training, e-course seminars, training of learning media with PowerPoint application, graphic design seminar, etc. used to enrich the media in the learning process in early childhood education.

\section{CONCLUSION}

The condition of resources owned by institutions is generally still lacking, such as the ability of educators who have not been optimal due to the availability of skill development sites that have not been supported and facilities that have not been adequate. The use of digital media in the learning in early childhood educational institutions has been widely used by teachers but used potluck. Digital media is considered necessary and used only for the purposes of learning only, such as the delivery of learning materials that can not be presented directly to children such as natural disasters, marine animals, wild animals, traditional dances, traditional houses and traditional clothing.

\section{REFERENCES}

[1] Ahmet, K., \& Nazenin, F. (2018) Investigating the Digital Addiction Level of the University Students According to Their Purposes for Using Digital Tools. Universal Journal of Educational Research 6(2): 235-241 
[2] Arslan, A., Kırık, AM, Karaman M, Çetinkaya A. (2015). Digital addiction in high school and university students. International PeerReviewed Journal of Communication And Humanities Research, 8(8): 34-58

[3] Castle, K. (2009). What do early childhood professionals do? Dimensions of Early Childhood, 37(3): 4-10.

[4] Chen, J. Q., \& Chang, C. (2006). Testing the whole teacher approach to professional development: A study of enhancing early childhood teachers' technology proficiency. Early Childhood Research \& Practice, 8(1), $1 \mathrm{e} 18$.

[5] Chen, J. Q., \& McCray, J. (2012). A Conceptual framework for teacher professional development: The whole teacher approach. NHSA Dialog, 15(1), 8e23.

[6] D.A. Lieberman et al. (2015). Young Children's Learning With Digital Media. [Online] Available: https://www.research gatenet/publication/232818900 (accessed 18 Juli 2018)

[7] Dewey, J. (2012). Democracy and Education. Courier Dover Publications.

[8] Ferrari, A. (2012). Digital Competence in Practice: An Analysis of Frameworks. Technical Report, European Commission, Joint Research Centre.

[9] Fisch, S., Shulman, J., Akerman, A., \& Levin, G. (2002). Reading between the pixels: Parentchild interaction while reading online storybooks. Early Education and Development, $13,435-451$

[10] Fullan, M. (1992). The New Menaning of Educational Change. Toronto: OISE Pres Publishing Co.

[11] I. R. Berson and M. J. Berson. (2010). HighTech Tots: Childhood in a Digital World, Charlotte, NC: Information Age Publishing.

[12] Lazar, I., Darlington, R. B., Murray, H.W., Royce, J., \& Snipper, A. (1982). Lasting effects of early education: A report from the consortium for longitudinal studies. Monographs of the Society for Research in Child Development, 47(2-3), 1-151
[13] Loretta, D., Green, T., and Hansen, L.E. (2012). One-to-One Laptop Teacher Education: Does Involvement Affect Candidate Technology Skills and Dispositions? Journal of Research on Technology in Education 44(2), 121-139

[14] McGee, L., \& Richgels, D. (2006). Can technology support emergent reading and writing? Directions for the future. In $M$. McKenna, L. Labbo, R. Kieffer, \& D. Reinking (Eds.), International handbook of literacy and technology, (Vol. 2, pp. 369-377). Mahwah, NJ: Erlbaum.

[15] Mizikaci, F. (2006). A systems approach to program evaluation model for quality in higher education. Quality Assurance in Education, 14(1), 37-53.

[16] National Association of the Education for Young Children. (2012). Technology and Interactive Media as Tools in Early Childhood Programs Serving Children from Birth through Age $8 . \quad$ [Online]. Available: https://www.naeyc.org/files/ naeyc/PS_technology_web.pdf

[17] Oden, S., Schweinhart, L.J., \& Weikart, D.P. (2000). Into adulthood: A study of the effects of head start. Ypsilanti, MI: High/Scope Educational Research.

[18] Priscilla. (2005). Fundamentals of Survey Research Methodology. [Online] Available: https://www.mitre.org/sites/ default/files/pdf/05_0638.pdf (accessed 18 Juli 2018).

[19] Segers, E., \& Verhoeven, L. (2002). Multimedia support of early literacy learning. Computers \& Education, 39, 207-221.

[20] Sujiono, Y. N. (2009). Konsep Pendidikan Anak Usia Dini. Jakarta: Indeks.

[21] Undang-Undang Republik Iindonesia Tentang Guru dan Dosen No.16 tahun 2006

[22] V. J. Rideout, A. Lauricella, and E. Wartella. (2013). Children, Media, and Race: Media Use among White, Black, Hispanic, and Asian American Children. Evanston, IL: Center on Media and Human Development, School of Communication, Northwestern University. [Online]. Available: http://web5.soc.north western.edu/cmhd/wp-ontent/uploads/ 201 1/06/SOCconfReportSingleFinal-1.pdf. 